\section{INSS - International Network for Survivors of Suicide}

\author{
Ved $\mathrm{M}$ argit Ferm
}

Vi i SPES ${ }^{1}$ hade under lång tid haft en vision om att tillsammans med systerorganisationer runt om i världen bygga ett stödjande, läran de, inspireran de nätverk för efterlevande till de som tagit sina liv. Drömmen blev verklighet den 25 augusti 2000 då vi bjöd in efterlevande från olika länder till en workshop i Stockholm. Syftet var att ge tillfälle för efterlevande att träffas och ta ställning till om vi skulle bilda en egen förening och samarbeta för att med gemensamma krafter lyfta fram suicidproblematiken som det folkhälsoproblem det är. D etta var första gången som efterlevande fick tillfälle att mötas på detta sätt. Det var representanter från Estland, Finland, N orge, U SA och Sverige, sammanlagt ca 40 personer.

\section{Inledningen}

Jag hade fått förtroendet att öppna workshopen och minns att jag bl a sade:

"Today is a day of hope,

today is a day of building network,

today is a day of co-operation,

today is a day of changing the future

with the help of each other,

we do hope nobody else will have

the same heavy experience

of a beloved one committing suicide."

Det var en märklig känsla som infann sig när vi hälsade på varandra, väl medvetna om att det som fört oss samman var det tyngsta som hänt var och en av oss. $\mathrm{N}$ är vi klädde denna känsla i ord och genom orden delade vad vi upplevde, rann tårarna inte bara av sorg utan också av glädje över att vi tillsammans var beslutna att åstadkomma förändringar så att andra inte skulle behöva uppleva det vi upplevt.

\section{INSS blir till}

På eftermiddagen beslöt vi att starta IN SS. Vi blev inbjudna att hålla nästa årskonferens i Estland och en interimsstyrel se utsågs, som skulle verka till dess.

Så här beskriver Else-M ay W irén, kassör i SPES sitt deltagande i det andra årsmötet. "Tillsammans med M argit Ferm fick jag möjligheten att vara med på IN SS andra konferens som hölls i Elva, några mil söder om universitetsstaden Tartu i Estland. $M$ ålet för konferensen var att skapa stadgar för den internationella organisationen, som tills nu bestått av Danmark, Estland, Finland, N orge, Sverige

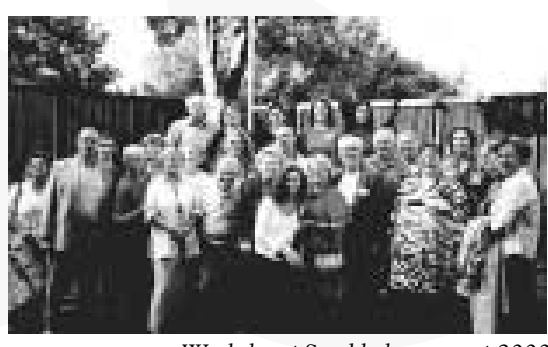

Workshop i Stockholm augusti 2000

och U SA . Tyvärr så hade många lämnat återbud. Vi representerade Estland, Sverige och M urmansk, Ryssland. Tack vare att $M$ argit fått fullmakter från U SA, Finland och N orge blev vi ändå beslutföra och kunde både utarbeta och anta stadgarna. Vi hade vissa kommunikationsproblem, den ryske representanten tal ade bara ryska och en representant från Estland enbart ryska och estniska. Tack vare den eminenta tolken, han var astronom, gick det mycket bra. Ryssland valdes in som medlem.

$M$ argit Ferm, Sverige valdes till president för IN SS fram till nästa årsmöte, A iri Värnik, Estland till inkommande president och Ingvald Liland, N orge, M onika A rnö, Finland, Serguey Salopine, Ryssland och Jerry W eyrauch, U SA till ledamöter i styrelsen. Jag själv och Ü lle Võhma valdes till revisorer. Så nu är arbetet i full gång."

\section{Hedersmedlemmar}

IN SS har hittills fyra hedersmedlemmar. Det är Prof. D anuta W asserman och Prof. Jan Beskow båda från Sverige. De stod faddrar 2000 då IN SS bildades och hade hela tiden stöttat tanken om en internationell sammanslutning för efterlevande. De har starkt bidragit till IN SS tillkomst. De övriga två hedersmedlemmarna återfinns in om W H O , D r W olfgang Rutz, och Dr Jose M. Bertolote. De har båda bidragit till W H O :s aktiva arbete med suicidprevention.

\section{WHO}

Så här säger Dr W olfgang R utz i sin hälsning till IN SS vid den tredje årskonferensen, som hölls 6-8 september i Stockholm.

"The World Health Organisation and its European programme on mental health consider the fight against suicide as one of its most important public health tasks.

Suicide afflicts an increasing number of victims, superseding in many countries the number of traffic deaths, causing immense suffering individually and amongst families, relatives and friends as well as demoralisation and losses economically and psychologically to societies.

Over the last four years, the WHO European programme on mental health has intensified its effort to prevent suicide, to raise awareness, to facilitate research, to monitor the suicidal, often very diverse situations in the European member states and to develop evidence-based and feasible national strategies of suicide prevention. A network has been created that presently is enlarging to include Eastern Europe, where problems are dramatic and needs overwhelming.

To take this responsibility, WHO needs crucially strong links and close co-operation with families and survivors whose experiences are decisive in our common task. Let me therefore, in my capacity as WHO Regional Adviser for mental health in Europe, honoured by an honorary membership in your organisation, but unable to be with you personally today, convene a greeting of compassion and participation to this important and timely meeting and express our strong wish for future, solidary and intensive collaboration.

On behalf of our Director, General Dr Gro Harlem Brundtland who is strongly and personally committed to issues of mental health improvement and suicide prevention, as well as our Regional Director, Dr Marc Danzon who himself is psychiatrist, I wish you all success."

\section{Fler medlemmar}

Vid de senaste årsmötena har antalet medlemmar ökat med Frankrike, U ruguay, Belgien, A ustralien och ytterligare organisationer har aviserat sitt inträde.

\section{Nuvarande verksamhet}

Jerry W eyrauch, SPA N, U SA tog över som president efter A iri Värnik, Estland vid årsmötet i september 2003. SPA N med Jerry och Elsie W eyrauch i ledningen har inspirerat oss genom sitt oförtröttliga arbete att väcka politikers och övriga besl utsfattares uppmärksamhet och öka deras förståels för att suicid är ett folkhälsoproblem som berör hel a samhället. G enom Jerry har IN SS pågåen de diskussioner med W HO om samarbete. På en fråga hur det kommer sig att de åstadkommit så mycket svarade Elsie W eyrauch att "W e laugh a lot, we hug a lot, we enjoy each other and we work hard!" Det har blivit IN SS motto!

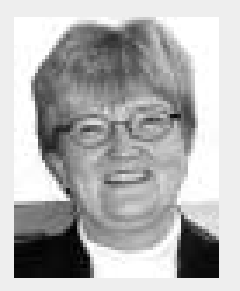

M argit Ferm O rdförande SPES $M$ ember of IN SS board as $\mathrm{H}$ istorian and Parlamentarian 